\title{
Technology Readiness and Digital Competing Capabilities: Digital Value Resonance
}

\author{
Roymon Panjaitan a, Agustinus Moonti ${ }^{b}$, Echan Adam ${ }^{c}$ \\ ${ }^{a}$ Faculty of Computer and Business, Universitas Sains dan Teknologi Komputer Semarang, Indonesia \\ $b^{b, c}$ Faculty of Agriculture, Universitas Negeri Gorontalo, Indonesia \\ Corresponding email: echanadam@ung.ac.id \\ doi http://dx.doi.org/10.22515/shirkah.v6i2.385
}

\begin{tabular}{|c|c|}
\hline ARTICLE INFO & ABSTRACT \\
\hline $\begin{array}{l}\text { Keywords: } \\
\text { Digital Competing } \\
\text { Capabilities; Digital Consumer } \\
\text { Habits; Digital Value } \\
\text { Resonance; Innovation } \\
\text { Products; Technology } \\
\text { Readiness } \\
\text { Article history: } \\
\text { Received: } 22 \text { February } 2021 \\
\text { Revised: } 03 \text { May } 2021 \\
\text { Accepted: } 12 \text { June } 2021 \\
\text { Available online: } 13 \text { July } 2021 \\
\text { To cite in APA style: } \\
\text { Panjaitan, R., Moonti, A., \& } \\
\text { Adam, E. (2021). Technology } \\
\text { Readiness and Digital } \\
\text { Competing Capabilities: } \\
\text { Digital Value Resonance. } \\
\text { Shirkah: Journal of Economics } \\
\text { and Business, 6(2), 205-226. }\end{array}$ & $\begin{array}{l}\text { The digital economy for MSMEs still possesses complex } \\
\text { problems in the debate over technology readiness and } \\
\text { competitive digital capabilities. The increase of dynamic } \\
\text { product innovation changes is only effectively supported by } \\
\text { digital value resonance. Addressing this issue, this research } \\
\text { aims to explore the readiness of technology and the ability to } \\
\text { compete digitally for innovative products through the } \\
\text { resonance of digital value, especially for multi-business } \\
\text { businesses. The data were collected from } 170 \text { respondents of } \\
\text { small and medium-sized businesses through questionnaires. } \\
\text { SEM-PLS techniques were used to analyze the data with a } \\
\text { path mediated by digital value resonance on product } \\
\text { innovation. The results showed that the resonance of digital } \\
\text { value successfully mediated the relationship of technological } \\
\text { readiness and digital competing capabilities, as well as direct } \\
\text { links to the improvement of innovative products. Digital } \\
\text { consumer habits also successfully strengthened the } \\
\text { relationship of technological readiness and digital } \\
\text { competing capabilities on the resonance of digital value. The } \\
\text { advantages of this research lie in the synthesis of proposed } \\
\text { digital value resonance variables from the results of } \\
\text { resource-based view theory propositions in bridging the } \\
\text { previous researcher gaps and contributing as a conceptual } \\
\text { novelty model that can personalize digital value in the level } \\
\text { of competition and increase MSMEs innovation products. }\end{array}$ \\
\hline
\end{tabular}

This work is licensed under a Creative Commons Attribution-NonCommercial 4.0 International License.

\section{Introduction}

The dynamics of innovation diffusion coherently demand business behavior towards global technological inventions. The readiness of digital technology disrupts traditional 
businesses, so it is necessary to breakthrough or stimulus digital competing capabilities in innovating. The insistence on the dissemination of technology readiness in small and medium enterprises according to Nugroho et al. (2017) stems from the habit of digital customers to obtain ease of use, accessibility and capital are factors that affect readiness in adopting information technology. The development of cloud computing technology in developing and developed countries focuses not only on large-scale industries but small-scale industries that have adopted e-commerce for retail and wholesale sales (Alam et al., 2011; Carcary et al., 2014; Ifinedo, 2011; Kurnia et al., 2015). An equally important discussion of the readiness of the adoption of this technology needs to be utilized to provide opportunities to expand the customer base, enter new product markets, and rationalize the business (Astuti \& Nasution, 2014; Walker et al., 2016). Therefore, businesses must be able to resonate digital value to the market to overcome the problem of technological readiness and digital competitive capabilities on the needs of product innovation. Figure 1 demonstrates that, according to World Bank Enterprises survey (2006-2014), only 4.2 percent of small companies in Indonesia have their website. This is in stark contrast to other countries in the Southeast Asian region, such as the Philippines and Vietnam.

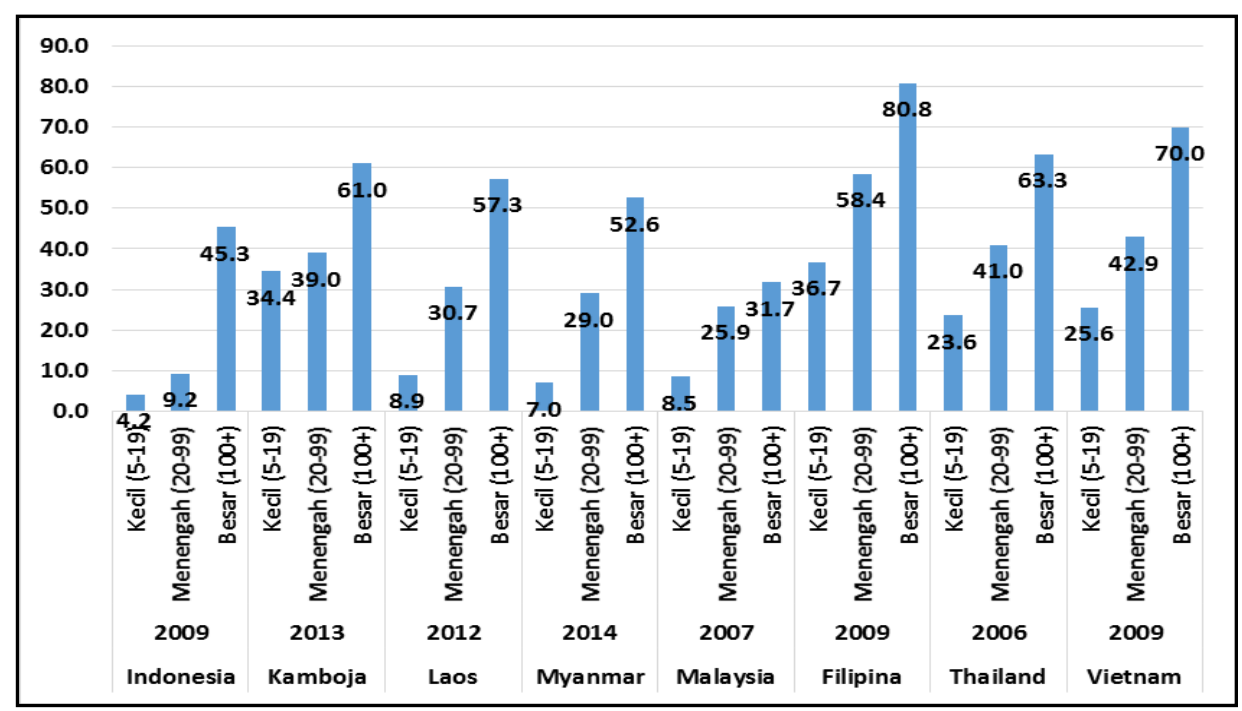

Figure 1. World Bank Enterprises Survey

In the resource theory by Barney et al. (2001) and Grant (1991), technology is one of the tangible resources that helps companies to explore opportunities for value creation or to avoid an environmental threat. In addition to the theoretical studies, according to Oliveira and Martins (2010) and Porter (2009), technology readiness includes professional skills, users, e-business, availability of the latest technology, absorption of technology by companies, PMA, internet users, broadband internet customers, and broadband internet. The role of technology becomes accustomed to changes in attitudes and enjoyment of consumption behavior (Handayani \& Martini, 
2014; Kusniadji, 2018; Rohimah, 2019; Sari, 2020a). Similarly, the theory of corporate resource learning initiated by Penrose (published 1959) cited again by Mahoney (1995) about two sources of corporate heterogeneity, namely resource connectivity and mental models can be intertwined.

The company's competitive strategy is an understanding of the competitive advantage it has over competitors, generating value for the organization, and doing so in a way that competitors cannot easily pursue (Barney, 1986, 1995). As technology evolves, the derivation of resource theory is refined in a comprehensive strategy that results in an online competing evolution strategy forcing real business actions to comply with customer demand and focus on long-term business continuity (Evans, 2001; Ilieva et al., 2002; Robertson \& Yu, 2001; Weber \& Polo, 2010). According to Bharadwaj et al. (2013) and Nguyen et al. (2015), the digital competition dimension consisting of digital business strategy and value creation. They further explains that the capabilities of online technology strategies positively affect product brand innovation. It also related to knowledge acquisition, market orientation, and brand innovation. Digital competing capabilities are also expected to stimulate innovation, technology, and dynamic capabilities. Therefore, the value of digital resonance is expected to echo the readiness and capability of competing technologies in a product innovation competition.

The current economic movement of MSMEs business is dominated by the influence of determining product innovation maneuvers simultaneously. There is a perspective that reflects the constellation of technological readiness forces that are important to businesses. As stated by Chang and Chen (2021), Lokuge et al. (2019), Okundaye et al. (2019), and Sun (2016), the role of digital innovation transforms the ease of use intentions of traditional systems towards high potential risk and provides a strong impact on the ease of transaction when businesses have a high level of technological readiness to earn rewards. Similarly, Halpern et al. (2021) state that organizational readiness can be used to accelerate the pace of innovation. The higher the technological readiness of each business assumes will improve the more product innovation. But behind the importance of technological readiness, there are inconsistencies in logical and practical perspectives that assume otherwise. Similarly, the opinion of Mohorčich \& Reese (2019) states that the readiness of technology experienced by manufacturers is more due to consumer activism when sellers feel more pressured by buyers in the supply chain. Another inconsistency of the impact of technological readiness is that the influence of changing demographics and the approaching age of retirement which causes individual responses to decrease when facing technology retraining (Larwood et al., 1997). Another study from Ahn and Yoon (2020) states that the trappings of poverty or the economy of middle-income businesses 
are obstacles encountered by the developing countries to explore product innovation opportunities.

Moreover, as pointed out by Malhotra and Hunt (2018), product innovation becomes a parameter of MSMEs to update their competencies to adapt to the current business environment. However, to the best of the authors' knowledge, no studies have contributed to offering a conceptual model with digital value resonance as a novelty, namely with the higher readiness of technology and digital competitive capabilities, the higher the resonance of digital value that can be echoed to the business environment. Digital value resonance is not a manifestation or result of technological readiness and digital competing capabilities but can be improved while businesses have high technological readiness and digital competing capabilities. Therefore, this research intends to shed some light on the importance of digital value resonance as a function of correlation that is of positive value to the improvement of innovative products. This research aims to provide solutions to the importance of resonating the digital value of MSMEs to be able to adapt to technological readiness and to be digitally competitive amid the increasing dynamics and sophisticated product innovations for business continuity.

\section{Hypothesis Development}

Technology Readiness, Digital Value Resonance, Product Innovation, and Digital Consumer Habits

Oliveira and Martins (2010) stated that the technology readiness factor is a significant facilitator for the adoption of e-commerce. Liljander et al. (2006) expressed a different opinion that technological readiness slightly affect a person or customer's attitude and behavior for technology adoption and evaluation. Liljander et al's. (2006) opinion can be a strong signal that the tendency to digital value resonance will run into obstacles. Technological readiness refers to people's tendency to embrace and use new technologies to achieve goals in life and at work, which can be seen from the four dimensions of personality, namely optimism, innovativeness, discomfort, and insecurity (Parasuraman, 2000).

The ability to produce innovative products is strongly supported by technological developments, such as technology-based companies can improve efficiency and effectiveness in producing products (Garcia \& Calantone, 2002). Innovation technology-based products are a prerequisite to increase product innovation in terms of unique acculturation products (Sugiyarti et al., 2018). Integrated computers enable flaw-free design and manufacturing excellence changes; thus enhancing the frequency of innovation (Kessler \& Chakrabarti, 1996).

Some researchers have suggested a link between technological orientation and product innovation as put forward by Yang et al. (2012) and Hortinha et al. (2011); that 
is, there is a positive relationship between technology orientation and product innovation. Zhou et al. (2005) also stated that technology orientation has a positive relationship with technology-based innovation but slightly influence the category of market-based innovation. Khin and Ho (2019) in their research stated that digital orientation and digital capabilities directly affect digital innovation.

Alluding to how consumer habits in the digital era, a study conducted by Sari (2020b) has proven that consumers today have become accustomed to and enjoy online purchases very much. Goodfellow (2011) also stated that digital technology had become a vital need no matter how old a person is. The advent of digital device mobility became an integral part of people's lives and also increased three important factors, i.e. speed, connectivity, and networking (Rivoltella, 2008). The digital age has been marked by the emergence of the "Digital Natives" generation. How the behaviors and habits of the digital generation of natives have been put forward by Cabanero-Johnson and Berge (2009), i.e. they live, breathe, work, and play with the tools and products of the digital age and they use these tools quite uniquely. The impact of technological readiness on the tendency of one's attitude to embrace and use new technologies as stated by Parasuraman (2000) will certainly be better if it is supported by habitual factors towards digital products as stated by Cabanero-Johnson and Berge (2009) regarding how digital natives behave. The exposure can be used as a basis to predict that technological readiness will have a significant influence on digital value resonance if moderated by digital consumer habits.

H1: Technology readiness has a negative influence on digital value resonance.

H2: Technology readiness has a negative influence on product innovation.

H3: Technology readiness has a positive influence on digital value resonance moderated by digital consumer habits.

Digital Competing Capabilities, Digital Value Resonance, Product Innovation, and Digital Consumer Habits

The concept of digital competing capability requires a critical understanding of three complementary and side-by-side aspects, namely technology, cognitive and social fields. This field of technology is supported by the knowledge, skills, and attitudes needed to explore the context of new technologies and deal with technological problems in a flexible way (Ferrari, 2012). The cognitive field is supported by the knowledge, skills, and attitudes needed to read, select, interpret, evaluate data and information taken to account for accuracy and reliability (Calvani et al., 2008). So the argument can be predicted that digital competition capabilities can affect the resonance of digital value because it is closely related to the social aspect, where knowledge and skills are needed to interact with others collaboratively to use technology.

The close relationship between digital technology capabilities and product 
innovation has been stated by researchers before. (Kristiansen et al., 2005), explained that media, including the internet, are used as a source of design and product innovation by small and medium enterprises (SMEs). (Khin \& Ho, 2019) in their research also stated that digital orientation and digital capabilities directly affect digital innovation. The above statement is proposed to be the basis of the hypothesis that there is a link between digital competing capability and product innovation.

Aspects of digital capability understanding related to the social field as stated by Calvani et al. (2008), such as how the need to interact with others using technology, are supported by Rivoltella (2008) that the mobility of digital devices is inseparable from people's lives and can increase three important factors, namely speed, virtuality, and network. The need of fast social interaction through the mobility of digital devices today has become a habit of society, especially for those called digital natives generation. Someone familiar with digital technology will find it difficult to interact with others who are not familiar with digital technology media. The argument can be predicted that the correlation of digital competition capability in digital value resonance can be improved by the moderation of digital consumer habits.

H4: Digital competing capabilities have a positive influence on digital value resonance.

H5: Digital competing capabilities have a positive influence on product Innovation

H6: Digital competing capabilities have a significant influence on digital value resonance moderated by digital consumer habits.

\section{Digital Value Resonance and Product Innovation}

The existence of technology can accelerate the development of new products. The company's ability to produce high technology and products with applied technology greatly affect the excellence of the products (Li \& Calantone, 1998). Wind and Mahajan (1997) stated that technology is one of the factors that influence the success of new products, whereby by using advanced technology, companies can create better products and innovations. From that opinion, a consumer, organization, or company in the digital age will tend to be difficult to produce innovative products if there is no effort to resonant with the value of digital technology in the era of industry 4.0 today.

Sugiyarti et al. (2018) also asserted that innovation technology-based products are a prerequisite for improving product innovation. Technology is the trigger for innovation, where companies are required and triggered to innovate in echoing the values of digital products according to the needs of the industrial era 4.0. Proof of the need for digital value is the emergence of the digital native's generation as revealed by Cabanero-Johnson and Berge (2009) should be the reason for product/service providers to produce innovative products that are always oriented to digital technology. Based on the exposure, the readiness of technology that is then followed up by digital value resonance efforts will affect product innovation. 
As well as technological readiness, digital technology capabilities are needed in the aspect of product innovation as described by Garcia and Calantone (2002), that to produce innovative products must be supported by the development of technology. The opinion of Kristiansen et al. (2005) is also very relevant where the media, including the internet, is used as a source of product innovation and design. The importance echoes the value of digital to provide added value to the relationship between technological capabilities and product innovation because many aspects related to technology and product innovation still have to involve the role of many parties.

H7: Digital value resonance has a positive influence on product innovation.

H8: Technology readiness has a significant influence on product innovation through digital value resonance

H9: Digital competing capabilities have a significant influence on product innovation through digital value resonance.

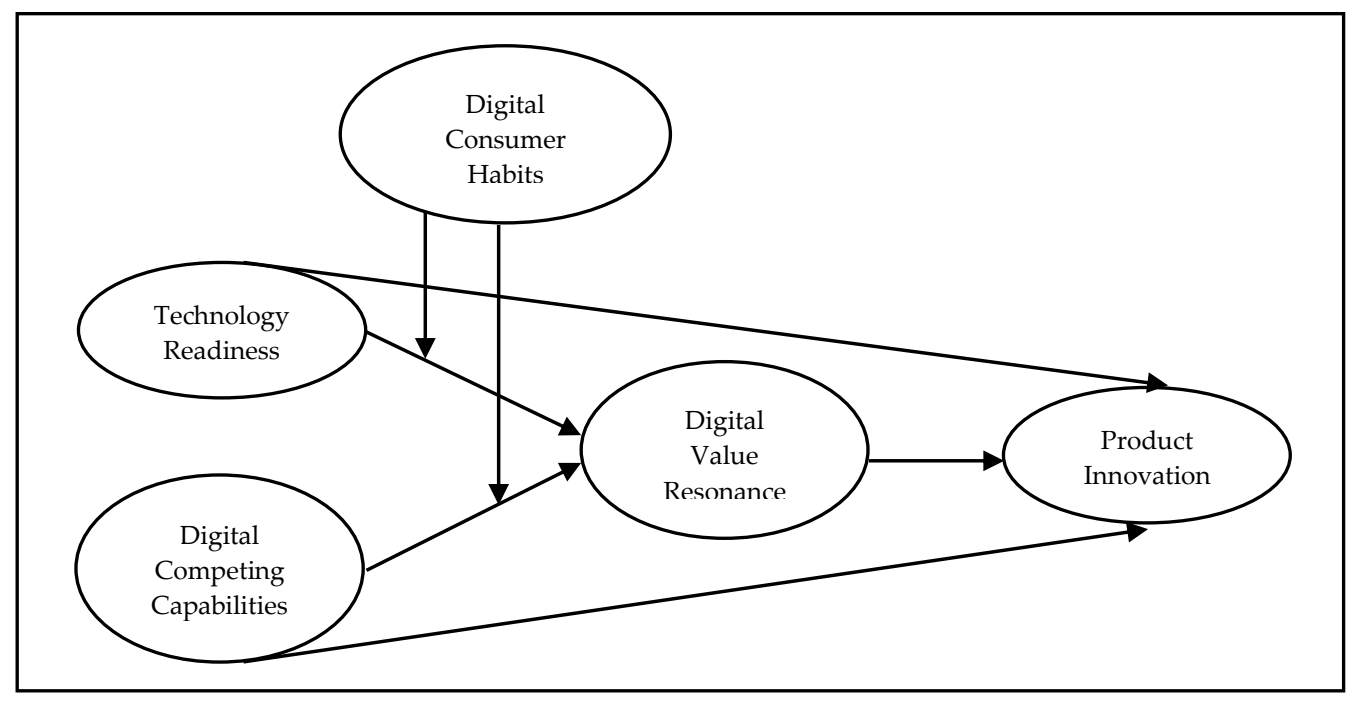

Figure 2. Research Model

\section{Method}

\section{Population and Samples}

This study aims to explain the role of technological readiness and the ability to compete digitally for innovative products through digital value resonance. The information of population in this study is shown in Table 1 . We use the convenience method for sampling. Respondents were given instruments in the form of online closed questionnaires to measure their perception of the digital value they used to innovate their products. Questionnaires are distributed online to actors of businesses and MSMEs located on the island of Java for a period of 2 months, namely from November to December 2020. During this period 170 respondents were selected for further 
statistical analysis. The number of samples is considered sufficient for research methods using SEM- PLS (Hair et al., 2012; Kock \& Hadaya, 2018).

Table 1. Demographic Information of the Respondents

\begin{tabular}{|c|c|c|c|c|}
\hline No. & Characteristics & & Total & $\%$ \\
\hline \multirow[t]{2}{*}{1.} & Sex & Male & 64 & 37,5 \\
\hline & & Female & 106 & 62,5 \\
\hline \multirow[t]{5}{*}{2.} & Age & $<20$ years & 27 & 16,2 \\
\hline & & $>20-30$ years & 40 & 23,5 \\
\hline & & $>30-40$ years & 90 & 52,9 \\
\hline & & $>40-50$ years & 9 & 5,1 \\
\hline & & $>50$ years & 4 & 2,2 \\
\hline \multirow[t]{4}{*}{3.} & Education & Senior High School & 24 & 13,2 \\
\hline & & Bachelor Degree & 104 & 61,0 \\
\hline & & Master Degree & 38 & 22,1 \\
\hline & & Doctoral Degree & 4 & 2,2 \\
\hline \multirow[t]{4}{*}{4.} & The duration of & $<3$ years & 4 & 2,2 \\
\hline & business & $>3-5$ years & 17 & 10,3 \\
\hline & & $>5-10$ years & 9 & 5,1 \\
\hline & & $>10$ years & 140 & 82,4 \\
\hline \multirow[t]{5}{*}{5.} & Income /month & $<$ Rp 10 Million & 1 & 0,7 \\
\hline & & > Rp 10 Million - Rp 25 Million & 9 & 11,0 \\
\hline & & > Rp 25 Million - Rp 100 Million & 146 & 86,0 \\
\hline & & > Rp 100 Million - Rp 200 Million & 3 & 1,5 \\
\hline & & > Rp 200 Million & 1 & 0,7 \\
\hline \multirow[t]{4}{*}{6.} & Type of Business & Online Business & 111 & 65,4 \\
\hline & & Manufacture & 4 & 2,2 \\
\hline & & Culinary & 26 & 15,4 \\
\hline & & Others & 29 & 17,0 \\
\hline
\end{tabular}

\section{Variable Measurenment}

Variable measurement items are adapted from previous research with modifications in adjusting to research objectives. All variables are measured using a five-point Likert scale, from Strongly Disagree to Strongly Agreeable. Research variables and their measurement indicators can be seen in Table 2.

Table 2. Operational Definition of Variables

\begin{tabular}{llll}
\hline Construct & Question & Dimension/Indicator & References \\
\hline Technology & 4 items & - Optimism & (Parasuraman \& Colby, \\
readiness & & - Innovation & 2015), (Rojas-Méndez et al., \\
& & - Discomfort & 2017), (Sani et al., 2020)
\end{tabular}




\begin{tabular}{|c|c|c|c|}
\hline Construct & Question & Dimension/Indicator & References \\
\hline $\begin{array}{l}\text { Digital } \\
\text { competing } \\
\text { capability }\end{array}$ & 7 items & $\begin{array}{l}\text { - Technology capability } \\
\text { - Dynamic capability } \\
\text { - Innovation capability } \\
\text { - Digital economy trends } \\
\text { - Digital business strategy } \\
\text { - Digital strategic } \\
\text { transformation } \\
\text { - Digital economy information }\end{array}$ & $\begin{array}{l}\text { (Lawson \& Samson, 2001), } \\
\text { (Yeh et al., 2015), (Arifin \& } \\
\text { Frmanzah, 2015), (Bharadwaj } \\
\text { et al., 2013), (Matt et al., 2015), } \\
\text { (Pagani, 2013), (Joshi et al., } \\
\text { 2015), (Şoavă et al., 2014) }\end{array}$ \\
\hline $\begin{array}{l}\text { Digital } \\
\text { value } \\
\text { resonance }\end{array}$ & 4 Items & $\begin{array}{l}\text { - Ability to design technology- } \\
\text { based systems } \\
\text { - Technology-based marketing } \\
\text { configuration skills } \\
\text { - Speed predicting } \\
\text { opportunities for technology- } \\
\text { based ideas } \\
\text { - Uniqueness of sales points }\end{array}$ & $\begin{array}{l}\text { (Sok et al., 2013), (Arifin et al., } \\
\text { 2018), (Zhou et al., 2005) }\end{array}$ \\
\hline $\begin{array}{l}\text { Product } \\
\text { innovation }\end{array}$ & 3 items & $\begin{array}{l}\text { - Motivation for innovation } \\
\text { development and product } \\
\text { ideas } \\
\text { - Product evaluation from } \\
\text { customers and suppliers } \\
\text { - Adaptation to environmental } \\
\text { change }\end{array}$ & $\begin{array}{l}\text { (Zhang \& Qu, 2020), (Jaeger } \\
\text { et al., 2017) (Ramkumar \& } \\
\text { Kulkarni, 2016) }\end{array}$ \\
\hline $\begin{array}{l}\text { Digital } \\
\text { consumer } \\
\text { habits }\end{array}$ & 6 items & $\begin{array}{l}\text { - Dynamic } \\
\text { - Experience } \\
\text { - Multichannel } \\
\text { - Artificial Intelligence } \\
\text { - Mobilization } \\
\text { - Product Sustainability }\end{array}$ & $\begin{array}{l}\text { (Saura, 2020), (Bissell, 2020), } \\
\text { (Met et al., 2020) }\end{array}$ \\
\hline
\end{tabular}

\section{Data Analysis}

The research model was analyzed using the SEM-PLS (Structural Equation ModelPartial Least Square) technique with smart PLS 3.0 software. SEM-PLS techniques can work effectively on small sample sizes with complex models. Also, SEM Techniques can test the effects of mediation simultaneously (Tabachnick \& Fidell, 2012). Model testing on SEM-PLS is conducted in two stages, namely testing the measurement model (outer model) and structural model (inner model).

\section{Measurement Model}

Measurement model testing consists of a test of the validity and reliability of the construct. The validity test consists of convergent validity and discriminant validity. The validity of convergence is used to assess the correlation between two sizes of the 
same concept. The loading factor value calculates the measurement of convergent validity of the reflective construct and the Average Variance Extracted (AVE) value which is the sum of squared standardized factors divided by the number of measurement items. The validity of convergence requires a loading factor value of 0.7 , and the AVE value must be higher than 0.5 (Hair et al., 2014). While the validity of the discriminant is measured by comparing the AVE value of both constructs with the square of the correlation between the two constructs tested. Discriminant validity is an assessment of how different a construct is from another. According to the Fornell \& Larcker (Fornell \& Larcker, 1981) criteria, the square root of each construct's AVE value must be higher than the correlation value between constructs in a model.

Reliability tests are used to determine the consistency of measurement results if measurements are performed twice or more of the same symptoms with the same measuring instrument. Reliability testing loading rules meet composite reliability criteria, and Cronbach's alpha is higher than 0.7; where 0.6 is still acceptable (Hair et al., 2014).

\section{Structural Model}

The structural model in this study was conducted to predict causality relationships between latent variables. The parameters used for model tests are the R-Square $\left(\mathrm{R}^{2}\right)$ value and the predictive relevance model $\left(Q^{2}\right)$. The high $R^{2}$ value reflects a better research model, while $\mathrm{Q}^{2}$ shows the level of results of the model as well as the estimated parameters that are well assessed from the observations made. The degree of significance in hypothesis testing is indicated by the value of the path coefficient (inner model). The loading rule of the path coefficient value indicated by the $t$-statistical value must be higher than 1.96 for the two-sided hypothesis in hypothesis testing using alpha 5\% (Hair et al., 2012).

\section{Results}

\section{Result of Measurement Model Test}

Based on validity and reliability testing, all items meet the requirements. All items on a variable have a loading factor value above 0.7 and an AVE value higher than 0.5. Reliability tests show composite reliability values and Cronbach's alpha $>0.7$ on all constructs. Thus it can be said that all variables in this study are valid and reliable. Validity and reliability test results are presented in Table 3.

Also, based on the testing of discriminant validity shows that all constructs in this research model have met the requirements. For each construct tested, the AVE square root value is higher than the correlation between constructs. This indicates that the validity of the discriminant is reached. The results of the discriminant validity test can be seen in Table 4. 
Table 3. Validity and Reliability Testing

\begin{tabular}{lllll}
\hline Variable & Indicator & STD. Loading & $\begin{array}{l}\text { P-values } \\
\mathbf{0 . 0 5}\end{array}$ & Status \\
\hline Technology readiness $\left(\mathrm{X}_{1}\right)$ & $\mathrm{X}_{1.1}$ & 0.961 & 0.000 & Valid \\
AVE $=0.889$ & $\mathrm{X}_{1.2}$ & 0.936 & 0.000 & Valid \\
CRI $=0.969$ & $\mathrm{X}_{1.3}$ & 0.916 & 0.000 & Valid \\
& $\mathrm{X}_{1.4}$ & 0.959 & 0.000 & Valid \\
Digital competing capability $\left(\mathrm{X}_{2}\right)$ & $\mathrm{X}_{2.1}$ & 0.965 & 0.000 & Valid \\
AVE $=0.916$ & $\mathrm{X}_{2.2}$ & 0.955 & 0.000 & Valid \\
CRI $=0.982$ & $\mathrm{X}_{2.3}$ & 0.954 & 0.000 & Valid \\
& $\mathrm{X}_{2.4}$ & 0.940 & 0.000 & Valid \\
& $\mathrm{X}_{2.5}$ & 0.970 & 0.000 & Valid \\
Digital value resonance $\left(\mathrm{Y}_{1}\right)$ & $\mathrm{Y}_{1.1}$ & 0.930 & 0.000 & Valid \\
AVE $=0.915$ & $\mathrm{Y}_{1.2}$ & 0.934 & 0.000 & Valid \\
CRI $=0.977$ & $\mathrm{Y}_{1.3}$ & 0.981 & 0.000 & Valid \\
& $\mathrm{Y}_{1.4}$ & 0.980 & 0.000 & Valid \\
Product innovation $\left(\mathrm{Y}_{2}\right)$ & $\mathrm{Y}_{2.1}$ & 0.957 & 0.000 & Valid \\
AVE $=0.939$ & $\mathrm{Y}_{2.2}$ & 0.984 & 0.000 & Valid \\
CRI $=0.979$ & $\mathrm{Y}_{2.3}$ & 0.965 & 0.000 & Valid \\
Digital consumer habits $(\mathrm{Z})$ & $\mathrm{Z}_{.1}$ & 0.757 & 0.000 & Valid \\
AVE $=0.525$ & $\mathrm{Z}_{.2}$ & 0.575 & 0.000 & Valid \\
CRI $=0.812$ & $\mathrm{Z}_{.3}$ & 0.867 & 0.000 & Valid \\
& $\mathrm{Z}_{.4}$ & 0.668 & 0.000 & Valid \\
\hline R-square $\left(\mathrm{R}^{2}\right)-\mathrm{Y}_{1}$ & 0,939 & & & \\
R-squared $\left(\mathrm{R}^{2}\right)-\mathrm{Y}_{2}$ & 0,965 & & & \\
Predictive relevance $\left(\mathrm{Q}^{2}\right)$ & 0,904 & & & \\
\hline
\end{tabular}

Table 4. Discriminant Validity

\begin{tabular}{lccccc}
\hline \multicolumn{1}{c}{ Variable } & Tr & Dcc & Dvr & Pi & Dch \\
\hline Technology readiness (Tr) $\left(\mathrm{X}_{1}\right)$ & $\mathbf{0 . 9 4 3}$ & & & & \\
Digital competing capability $(\mathrm{Dcc})\left(\mathrm{X}_{2}\right)$ & 0.893 & $\mathbf{0 . 9 5 7}$ & & & \\
Digital value resonance (Dvr) $\left(\mathrm{Y}_{1}\right)$ & 0.876 & 0.902 & $\mathbf{0 . 9 5 6}$ & & \\
Product innovation (Pi) $\left(\mathrm{Y}_{2}\right)$ & 0.855 & 0.947 & 0.913 & $\mathbf{0 . 9 6 9}$ & \\
Digital consumer habits (Dch) $(\mathrm{Z})$ & 0.129 & 0.125 & 0.106 & 0.132 & $\mathbf{0 . 7 1 7}$ \\
\hline
\end{tabular}

\section{Result of Structural Model Test}

Structural model test results showed that the $\mathrm{Q}^{2}$ digital value resonance was $90.4 \%$. This suggests that the research model is good. Based on the results of statistical tests conducted with bootstrap analysis, the 5 hypotheses of direct influence submitted are all confirmed. The construct directly affects digital value resonance as well as product innovation. The influence of technology readiness $(1,364)$ has a significant negative effect on digital value resonance and (0.249) on product innovation with $\mathrm{p}$-value $<0.05$ 
respectively so that $\mathrm{H} 1$ and $\mathrm{H} 2$ are confirmed. Digital competing capability has a positive and significant direct influence on Digital value resonance $(2,317)$ and Product innovation $(1,047)$ and confirms $\mathrm{H} 4$ and H5. Furthermore, the direct influence of digital value resonance variable $(0.171)$ on product innovation is a significant positive with a p-value $<0.10$ so that $\mathrm{H} 7$ is not rejected.

Furthermore, the 4 hypotheses of indirect influence of both moderation and mediation are all confirmed at $\mathrm{p}$-value $<0.05$ and $\mathrm{p}$-value $<0.10$. Variable digital consumer habits $(2,380)$ moderate positively and significantly technology readiness against digital value resonance, while moderation $(2,556)$ of technology readiness to digital value resonance is negative and significant, and $\mathrm{H} 3$ and $\mathrm{H} 6$ are confirmed. Also, variable digital value resonance $(0.233)$ can mediate the influence of technology readiness on product innovation and also able to mediate $(0.340)$ the influence of digital competing capability on product innovation. Therefore, these results support $\mathrm{H} 8$ and H9.

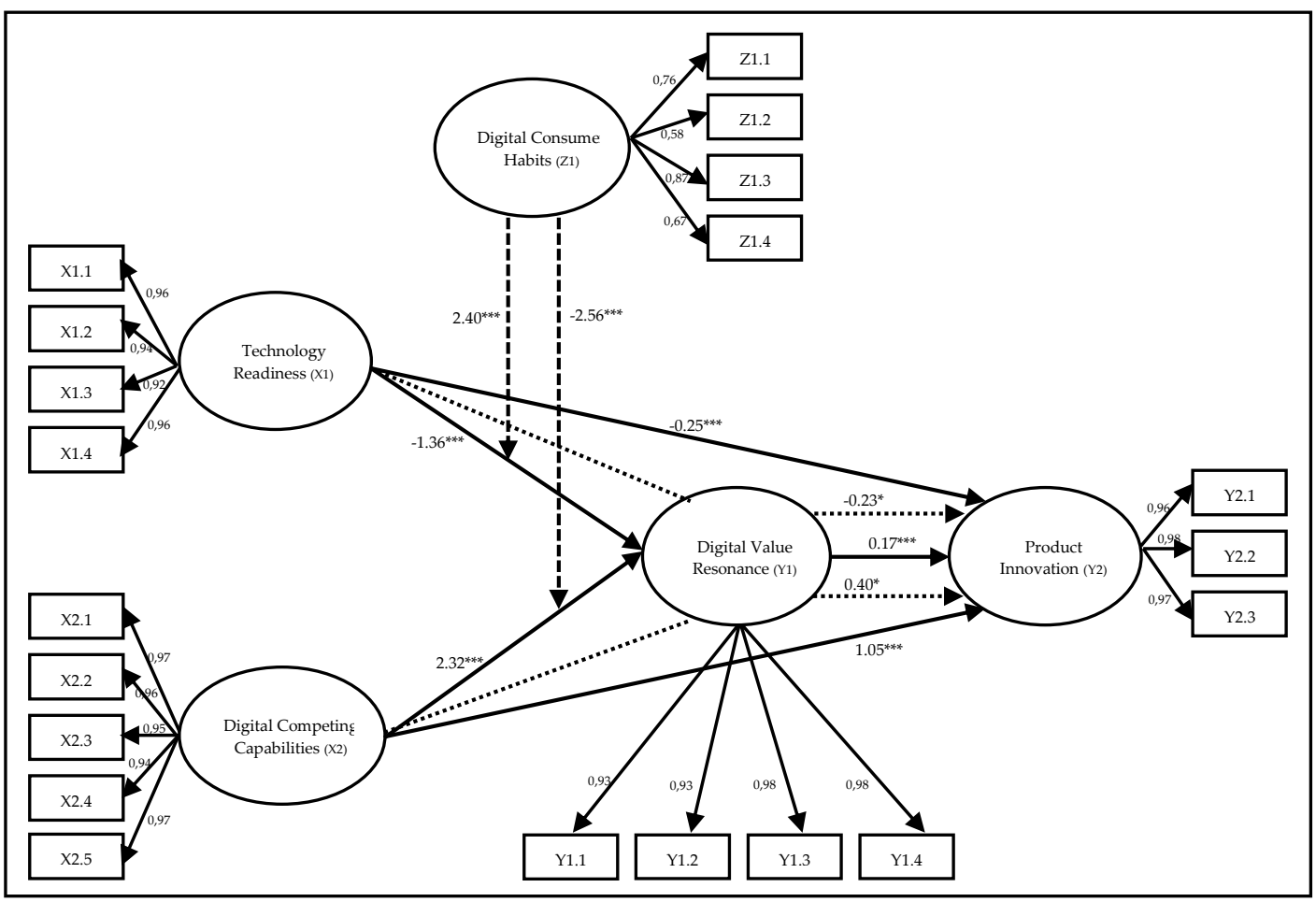

Figure 3. Structural Model of Digital Value Resonance and Product Innovation

Information:

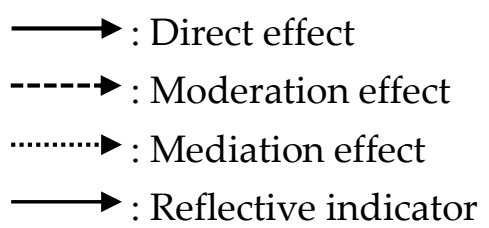


Table 5. Hypothesis Testing Results

\begin{tabular}{|c|c|c|c|c|}
\hline Hypothesis & Direct \& Indirect Effect & Estimate & T-Value & Result \\
\hline H1 & $\operatorname{Tr}(\mathrm{X} 1) \rightarrow \operatorname{Dvr}(\mathrm{Y} 1)$ & $-1.3639^{* * *}$ & 4.3346 & Supported \\
\hline $\mathrm{H} 2$ & $\operatorname{Tr}(\mathrm{X} 1) \rightarrow \operatorname{Pi}(\mathrm{Y} 2)$ & $-0.2494^{* * *}$ & 2.8809 & Supported \\
\hline H3 (Mo) & $\operatorname{Tr}(\mathrm{X} 1){ }^{*} \operatorname{Dch}(\mathrm{Z} 1) \rightarrow \operatorname{Dvr}(\mathrm{Y} 1)$ & $2.3793^{* * *}$ & 4.8593 & Supported \\
\hline $\mathrm{H} 4$ & $\operatorname{Dcc}(\mathrm{X} 2) \rightarrow \operatorname{Dvr}(\mathrm{Y} 1)$ & $2.3172^{* * *}$ & 8.1237 & Supported \\
\hline H5 & $\operatorname{Dcc}(\mathrm{X} 2) \rightarrow \operatorname{Pi}(\mathrm{Y} 2)$ & $1.0474^{* * *}$ & 10.9994 & Supported \\
\hline H6 (Mo) & $\begin{array}{l}\operatorname{Dcc}(X 2) * \operatorname{Dch}(\mathrm{Z} 1) \rightarrow \operatorname{Dvr} \\
(\mathrm{Y} 1)\end{array}$ & $-2.5558^{* * *}$ & 5.0148 & Supported \\
\hline $\mathrm{H} 7$ & $\operatorname{Dvr}(\mathrm{Y} 1) \rightarrow \operatorname{Pi}(\mathrm{Y} 2)$ & $0.1705^{*}$ & 1.5485 & Supported \\
\hline H8 (Me) & $\operatorname{Tr}(\mathrm{X} 1) \rightarrow \operatorname{Dvr}(\mathrm{Y} 1) \rightarrow \operatorname{Pi}(\mathrm{Y} 2)$ & $-0.2325^{*}$ & -1.4250 & Supported \\
\hline $\mathrm{H9}(\mathrm{Me})$ & $\begin{array}{l}\operatorname{Dcc}(\mathrm{X} 2) \rightarrow \operatorname{Dvr}(\mathrm{Y} 1) \rightarrow \mathrm{Pi} \\
(\mathrm{Y} 2)\end{array}$ & $0.3951^{*}$ & 1.5102 & Supported \\
\hline
\end{tabular}

Note: All $t$-statistics are sig. at $p<1 \%\left({ }^{* * *}\right) ; 5 \%(* *) ; 10 \%\left({ }^{*}\right)$.

$\mathrm{Mo}=$ Moderation effect; $\mathrm{Me}=$ Mediation effect.

$\mathrm{Tr}=$ Technology readiness; $\mathrm{Dcc}=$ Digital competing capability; $\mathrm{Dvr}=$ Digital value resonance; $\mathrm{Pi}=$ Product innovation; Dch = Digital consumer habits.

\section{Discussion}

The results showed that technology readiness has a negative influence on digital value resonance to improve product innovation capabilities. MSMEs businesses with low technological readiness need to echo digital value, so that product innovation can be improved. The resonance of digital value in this study became the determining factor even though MSMEs businesses are not ready to adopt the technology. This study empirically reinforces the findings of Liljander et al. (2006) where technology readiness slightly contributes to the adoption of technology. Clausing and Holmes (2010), Demirci and Ersoy (2008), Westjohn et al. (2009) found that technological readiness makes business owners easily adopt and use technology so that it supports decisions and improves product performance on a technology basis. The factor that encourages MSMEs businesses to increase the resonance of digital value is that MSMEs believe digital business transformation strategies can be future business opportunities. Digital consumer habits have an important role for MSMEs who sell products online, making it profitable for those who adopt and use technology on products.

The results of this study also showed that technological readiness has an indirect influence in innovating products through digital value resonance. Business opportunities on digital transformation, uniqueness of products produced, accurate product design, and ease of selling products through digital technology can support the readiness of MSMEs businesses in the adoption and use of technology and motivate them to innovate products. This research empirically proves that digital value factors determine the readiness of the technology for MSMEs businesses in facing the market. 
Similarly, Garcia and Calantone (2002), Cabanero-Johnson and Berge (2009), Sugiyarti et al. (2018) prove the positive effects of digital value resonance such as native digital generation habits on the adoption and use of technology in producing innovative products. Therefore, the digital value or benefits of technology must continue to be echoed, which further allows MSMEs businesses to innovate on products to be marketed.

Different results in MSMEs businesses with digital competing capability, which has a positive and significant effect on digital value resonance. Businesses with high digital concepts need to be supported with the knowledge, skills, and attitude to explore the context of new technologies and require interaction with others together in using technology. This must certainly be done by MSMEs businesses in meeting the technological, cognitive, and social aspects of the concept of digital competing capability, to resonate digital value. With digital competing capability owned by MSMEs businesses, giving them a coherent framework to develop and manage capabilities in a way that will build competitive advantage. Empirically this result reinforces the opinion of Calvani et al. (2008), Ferrari (2012), and Teece (2013) findings, where a close relationship can occur between the improvement of digital capability indicators and the advantages in competing from the use of digital technology. Furthermore, this significant influence gets a negative response when it is present in consumers with low digital habits. This can happen if consumers have strong control beliefs about factors that inhibit behavior in accepting and absorbing new technologies. Low perception of the development of digital technology can decrease the ability to compete digitally for MSMEs even though it has echoed digital values. These results are reinforced by the findings of Afriani and Halmawati (2019), Paramita et al. (2018), which states that overconfidence towards knowledge leads to self-restriction of technology adoption and decision-making of new things.

Digital competing capabilities owned by MSMEs businesses are also able to increase product innovation. MSME businesses with technology capabilities, dynamic capabilities, and proven innovation capabilities will be quickly motivated to develop and implement new product ideas. The results of this study are following the findings of Zhou and Li (2010), Bughin and Zeebroeck (2017), Khin and Ho (2019), where digital competing capabilities are needed to integrate digital technology with professional digital talent. From this research, digital competing capabilities can be considered as dynamic capabilities, which are described as the ability of organizations or MSMEs to innovate new products.

The results of this study also found that digital competing capability can improve the product innovation capabilities of MSMEs businesses by resonating digital values. However, the result of this indirect influence obtained a lower value (0.395) compared 
to the direct effect $(1,047)$ indicating the partial mediation effect of digital value resonance to fill the gap between digital competing capability and innovation product. Thus, this finding emphasizes that the potential of real digital value resonance can mediate MSMEs to optimize product innovation. Most of the respondents in this study were online business actors with a turnover between IDR 25 million to IDR 100 million. It means that some types of real businesses increase their revenue by adopting technology, the resonance of digital value, and can compete digitally in improving product innovation.

\section{Implication}

Dissemination and literacy of digital product technology create competitiveness, both local, national and foreign MSMEs. Indonesia's growing population makes it a potential market share for MSMEs in offering contemporary innovations through the benefits of technology. Almost nowadays all promotional media is done through technology media. It is very important to know the driving factors of technological readiness so that the potential market share is increasingly competing to offer different products to be manufacturers that contribute to consumers.

The explanation of this study describes that respondents as potential business actors know about digital technology, but from demographic character, subject, and objectivity, not all are able to respond the emergence of technology. This shows that MSMEs businesses are not fully able to operate all the latest technological features that exist in the market today. Readiness is an important factor during the boom of advanced technology that is increasingly updated. Digital consumer behavior has a positive implication on the demands of ease and speed of access to demand MSMEs to synergize to have competitiveness in product innovation changes. Therefore, from the limitations of operational capabilities, efforts to promote digital value through intelligent features can improve the digital competence of users who are oriented to product innovation.

\section{Conclusion}

In conclusion, this study concentrates on investigating the factors that drive the readiness of competitive technology to improve innovative products in MSMEs. From the results of statistical tests, it was revealed that the impact of technological readiness and digital competitive capabilities have a significant positive effect to make changes to the improvement of innovation. Critical factors in this research seek to echo the value of digital at the level of technological readiness and certainly have competitiveness competencies. These results show that the main determining factor in echoing the value that exists in digital technology is so important in the face of the dynamics of innovation diffusion and practical oriented to the needs of consumer services. The higher the level of technological readiness felt the higher the value of digital resonance to be 
disseminated. On the contrary, the lower the readiness of technology will affect decreasing product innovation, so the resonance of digital value can bridge the digital values of the relationship of readiness and digital competitive capabilities. This study successfully revealed that digital consumer habits can strengthen the response of technological readiness and competitive capabilities in absorbing digital values in product innovation. Digital technology service providers can take advantage of the findings of this study. Therefore, optimization of digital value resonance which in turn will have an impact on improving the maneuverability of the latest product innovations. Thus, the presence of digital value resonance can echo the value of digital technology for MSMEs and digital consumers.

Current research has some limitations. First, the sample size is relatively small which is less than 200 respondents, and respondents are still focused on Java Island. Second, the characteristics of respondents are still dominated by tech-savvy millennial, so understanding the use of technology features is better than parents'. About these limitations, generalizing the findings of the study requires broader dissemination. The study recommends that future researchers should investigate the role of augmented reality technology in empowering local brands in dealing with foreign brands and explore the effects of moderators. It was found that most respondents knew about technology but we're not all yet able to create a competitive technology medium to meet their business. Furthermore, this study suggests future studies to include variable information technology dexterity influenced by market sensing capabilities and brand management capabilities in improving the productivity of MSMEs business performance.

\section{Acknowledgement}

We express our special thanks to all creative businesses and MSME owners who have voluntarily participated in filling out our research questionnaire. We also would like to express our gratitude to the University of STEKOM for their moral support during the completion of this article.

\section{Authors' Declaration}

The authors made substantial contributions to the conception and design of the study. The authors took responsibility for data analysis, interpretation and discussion of results. The authors read and approved the final manuscript.

\section{ORCID}

Raymond Panjaitan (D) https://orcid.org/0000-0002-5901-1682

Agustinus Moonti (D) https://orcid.org/0000-0001-9854-2606

Echan Adam (D) https://orcid.org/0000-0002-6976-9817 


\section{References}

Afriani, D., \& Halmawati, H. (2019). Pengaruh Cognitive Dissonance Bias, Overconfidence Bias Dan Herding Bias Terhadap Pengambilan Keputusan Investasi. Jurnal Eksplorasi Akuntansi, 1(4), 1650-1665. https://doi.org/10.24036/jea.v1i4.168

Ahn, S. J., \& Yoon, H. Y. (2020). 'Green chasm' in clean-tech for air pollution: Patent evidence of a long innovation cycle and a technological level gap. Journal of Cleaner Production. 272, 1-15. https://doi.org/10.1016/j.jclepro.2020.122726

Alam, S. S., Ali, M. Y., \& Jani, M. F. M. (2011). An empirical study of factors affecting electronic commerce adoption among SMEs in Malaysia. Journal of Business Economics and Management, 12(2), 375-399. https://doi.org/10.3846/16111699.2011.576749

Arifin, A. H., Sullaida, S., \& Nurmala, N. (2018). The Relationship of Job Satisfaction, Transformational Leadership, and Work Discipline on Performance Employee With Organizational Commitment As Intervening Variable of Administration Staffs At State Malikussaleh University. Indonesian Journal of Educational Review, 5(1), 52-67. https://doi.org/10.21009/IJER.05.01.08

Arifin, Z., \& Frmanzah. (2015). The Effect of Dynamic Capability to Technology Adoption and its Determinant Factors for Improving Firm's Performance; Toward a Conceptual Model. Procedia - Social and Behavioral Sciences, 207, 786796. https://doi.org/10.1016/j.sbspro.2015.10.168

Astuti, N. C., \& Nasution, R. A. (2014). Technology readiness and E-commerce adoption among entrepreneurs of SMEs in Bandung city, Indonesia. Gadjah Mada International Journal of Business, 16(1), 69-88. https://doi.org/10.22146/gamaijb.5468

Barney, J. B. (1986). Organizational Culture: Can It Be a Source of Sustained Competitive Advantage? Academy of Management Review, 11(3), 656-665. https://doi.org/10.5465/amr.1986.4306261

Barney, J. B. (1995). Looking inside for competitive advantage. Academy of Management Perspectives, 9(4), 49-61. https://doi.org/10.5465/ame.1995.9512032192

Barney, J., Wright, M., \& Ketchen, D. J. (2001). The resource-based view of the firm: Ten years after 1991. In Journal of Management, 27(6), 625-641. https://doi.org/10.1016/S0149-2063(01)00114-3

Bharadwaj, A., El Sawy, O. A., Pavlou, P. A., \& Venkatraman, N. (2013). Digital business strategy: Toward a next generation of insights. MIS Quarterly: Management Information Systems, 37(2), 471-482. https://doi.org/10.25300/MISQ/2013/37:2.3

Bissell, D. (2020). Affective platform urbanism: Changing habits of digital on-demand consumption. Geoforum, 115, 102-110. https://doi.org/10.1016/j.geoforum.2020.06.026

Bughin, J., \& Zeebroeck, N. van. (2017). The Best Response to Digital Disruption. MIT Sloan Management Review, 58(4), 80-86.

Cabanero-Johnson, P. S., \& Berge, Z. (2009). Digital natives: Back to the future of microworlds in a corporate learning organization. The Learning Organization, 
16(4), 290-297. https://doi.org/10.1108/09696470910960383.

Calvani, A., Cartelli, A., Fini, A., \& Ranieri, M. (2008). Models and instruments for assessing digital competence at school. Journal of E-Learning and Knowledge Society, 4(3), 183-193.

Carcary, M., Doherty, E., \& Conway, G. (2014). The Adoption of Cloud Computing by Irish SMEs - an Exploratory Study. Electronic Journal of Information Systems Evaluation, 17(1), 3-14.

Chang, Y. W., \& Chen, J. (2021). What motivates customers to shop in smart shops? The impacts of smart technology and technology readiness. Journal of Retailing and Consumer Services, 58, 1-11. https://doi.org/10.1016/j.jretconser.2020.102325

Clausing, D., \& Holmes, M. (2010). Technology readiness. Research-Technology Management, 53(4), 52-59.

Demirci, A. E., \& Ersoy, N. F. (2008). Technology readiness for innovative high-tech products: how consumers perceive and adopt new technologies. The Business Review, 11(1), 302-308.

Evans, C. (2001). An E-strategy for online E-business. Information Systems Management, 18(4), 8-21. https://doi.org/10.1201/1078/43198.18.4.20010901/31461.2

Ferrari, A. (2012). Digital competence in practice: An analysis of frameworks. Sevilla: JRC IPTS.

Fornell, C., \& Larcker, D. F. (1981). Evaluating Structural Equation Models with Unobservable Variables and Measurement Error. Journal of Marketing Research, 18(1), 39-50. https://doi.org/10.2307/3151312

Garcia, R., \& Calantone, R. (2002). A critical look at technological innovation typology and innovativeness terminology: a literature review. Journal of Product Innovation Management: An International Publication of the Product Development \& Management Association, 19(2), 110-132.

Goodfellow, R. (2011). Literacy, literacies and the digital in higher education. Teaching in Higher Education, 16(1), 131-144.

Grant, R. M. (1991). The Resource-Based Theory of Competitive Advantage: Implications for Strategy Formulation. California Management Review, 33(3), 114135. https://doi.org/10.2307/41166664

Hair, J. F., Black, W. C., Babin, B. J., \& R. E. D. (2014). Multivariat Data Analysis. 7th Edition (7th ed.). USA: Pearson Education Limited.

Hair, Joe F, Sarstedt, M., Ringle, C. M., \& Mena, J. A. (2012). An assessment of the use of partial least squares structural equation modeling in marketing research. Journal of the Academy of Marketing Science, 40(3), 414-433.

Halpern, N., Mwesiumo, D., Suau-Sanchez, P., Budd, T., \& Bråthen, S. (2021). Ready for digital transformation? The effect of organizational readiness, innovation, airport size and ownership on digital change at airports. Journal of Air Transport Management, 90, 1-11. https://doi.org/10.1016/j.jairtraman.2020.101949

Handayani, S., \& Martini, I. (2014). Model Pemasaran di Era New Wave Marketing. Jurnal Ekonomi Manajemen Dan Akuntansi, 21(36), 1-12.

Hortinha, P., Lages, C., \& Lages, L. F. (2011). The trade-off between customer and technology orientations: impact on innovation capabilities and export 
performance. Journal of International Marketing, 19(3), 36-58.

https://doi.org/10.1509\%2Fjimk.19.3.36

Hunt, S. D., \& Morgan, R. M. (2018). The Resource-Advantage Theory of Competition. In Review of Marketing Research, 4, 1-53. https://doi.org/10.4324/9781315088747-4

Ifinedo, P. (2011). Internet/e-business technologies acceptance in Canada's SMEs: An exploratory investigation. Internet Research, 21(3), 255-281.

https://doi.org/10.1108/10662241111139309

Ilieva, J., Baron, S., \& Healey, N. M. (2002). Online Surveys in Marketing Research. International Journal of Market Research, 44(3), 1-14. https://doi.org/10.1177/147078530204400303

Jaeger, S. R., Cardello, A. V., Chheang, S. L., Beresford, M. K., Hedderley, D. I., \& Pineau, B. (2017). Holistic and consumer-centric assessment of beer: A multimeasurement approach. Food Research International, 99, 287-297. https://doi.org/10.1016/j.foodres.2017.05.004

Joshi, G. P., Acharya, S., \& Kim, S. W. (2015). Fuzzy-logic-based channel selection in IEEE 802.22 WRAN. Information Systems, 48, 327-332. https://doi.org/10.1016/j.is.2014.05.009

Kessler, E. H., \& Chakrabarti, A. K. (1996). Innovation speed: A conceptual model of context, antecedents, and outcomes. Academy of Management Review, 21(4), 1143 1191.

Khin, S., \& Ho, T. C. F. (2019). Digital technology, digital capability and organizational performance. International Journal of Innovation Science, 11(2), 177-195. https://doi.org/10.1108/IJIS-08-2018-0083

Kock, N., \& Hadaya, P. (2018). Minimum sample size estimation in PLS-SEM: The inverse square root and gamma-exponential methods. Information Systems Journal, 28(1), 227-261. https://doi.org/10.1111/isj.12131

Kristiansen, S., Kimeme, J., Mbwambo, A., \& Wahid, F. (2005). Information flows and adaptation in Tanzanian cottage industries. Entrepreneurship \& Regional Development, 17(5), 365-388.

Kurnia, S., Choudrie, J., Mahbubur, R. M., \& Alzougool, B. (2015). E-commerce technology adoption: A Malaysian grocery SME retail sector study. Journal of Business Research, 68(9), 1906-1918. https://doi.org/10.1016/j.jbusres.2014.12.010

Kusniadji, S. (2018). Kontribusi Penggunaan Personal Selling Dalam Kegiatan Komunikasi Pemasaran Pada Era Pemasaran Masa Kini. Jurnal Komunikasi, 9(2), 176-183. https://doi.org/10.24912/jk.v9i2.1078

Larwood, L., Ruben, K., Popoff, C., \& Judson, D. H. (1997). Aging, retirement, and interest in technological retraining: Predicting personal investment and withdrawal. Journal of High Technology Management Research, 8(2), 277-300. https://doi.org/10.1016/S1047-8310(97)90007-9

Lawson, B., \& Samson, D. (2001). Developing innovation capability in organizations: a dynamic capabilities approach. International journal of innovation management, 5(03), 377-400.

Li, T., \& Calantone, R. J. (1998). The impact of market knowledge competence on new product advantage: conceptualization and empirical examination. Journal of 
Marketing, 62(4), 13-29.

Liljander, V., Gillberg, F., Gummerus, J., \& Van Riel, A. (2006). Technology readiness and the evaluation and adoption of self-service technologies. Journal of Retailing and Consumer Services, 13(3), 177-191.

Lokuge, S., Sedera, D., Grover, V., \& Dongming, X. (2019). Organizational readiness for digital innovation: Development and empirical calibration of a construct. Information and Management, 56(3), 445-461. https://doi.org/10.1016/j.im.2018.09.001

Mahoney, J. T. (1995). The management of resources and the resource of management. Journal of Business Research, 33(2), 91-101. https://doi.org/10.1016/01482963(94)00060-R

Matt, C., Hess, T., \& Benlian, A. (2015). Digital transformation strategies. Business $\mathcal{E}$ Information Systems Engineering, 57(5), 339-343.

Met, İ., Uysal, E. U., Özkaya, K. S., \& Orç, E. (2020). Key Success Factors for Strategic Management in Digital Business. Digital Business Strategies in Blockchain Ecosystems. Springer, Cham., 283-304. https://doi.org/10.1007/978-3-030-29739-8_13

Mohorčich, J., \& Reese, J. (2019). Cell-cultured meat: Lessons from GMO adoption and resistance. Appetite, 143, 1-9. https://doi.org/10.1016/j.appet.2019.104408

Nguyen, B., Yu, X., Melewar, T. C., \& Chen, J. (2015). Brand innovation and social media: Knowledge acquisition from social media, market orientation, and the moderating role of social media strategic capability. Industrial Marketing Management, 51, 11-25. https://doi.org/10.1016/j.indmarman.2015.04.017

Nugroho, M. A., Susilo, A. Z., Fajar, M. A., \& Rahmawati, D. (2017). Exploratory Study of SMEs Technology Adoption Readiness Factors. Procedia Computer Science, 124, 329-336. https://doi.org/10.1016/j.procs.2017.12.162

Okundaye, K., Fan, S. K., \& Dwyer, R. J. (2019). Impact of information and communication technology in Nigerian small-to medium-sized enterprises. Journal of Economics, Finance and Administrative Science, 24(47), 29-46. https://doi.org/10.1108/JEFAS-08-2018-0086

Oliveira, T., \& Martins, M. F. (2010). Understanding e-business adoption across industries in European countries. Industrial Management and Data Systems, 110(9), 1337-1354. https://doi.org/10.1108/02635571011087428

Pagani, M. (2013). Digital business strategy and value creation: Framing the dynamic cycle of control points. Mis Quarterly, 37(2), 617-632.

Paramita, R. S., Isbanah, Y., \& Purwohandoko. (2018). Bias Kognitif dan Kepribadian Individu: Studi Perilaku Investor Muda di Surabaya. Jurnal Riset Manajemen Sains Indonesia, 9(2), 214-235.

Parasuraman, A., \& Colby, C. L. (2015). An Updated and Streamlined Technology Readiness Index: TRI 2.0. Journal of Service Research, 18(1), 59-74. https://doi.org/10.1177/1094670514539730

Parasuraman, A. (2000). Technology Readiness Index (TRI) a multiple-item scale to measure readiness to embrace new technologies. Journal of Service Research, 2(4), 307-320.

Porter, M. E. (2009). The Global Competitiveness Report 2008 - 2009. In Forum 
American Bar Association (Vol. 1).

Ramkumar, P. L., \& Kulkarni, D. M. (2016). Impact strength investigation of foamed linear low density polyethylene in rotational moulding process. International Journal of Materials Engineering Innovation, 7(3-4), 159-174. https://doi.org/10.1504/IJMATEI.2016.084617

Rivoltella, P. C. (2008). Digital literacy: Tools and methodologies for information society. IGI Global.

Robertson, P. L., \& Yu, T. F. (2001). Firm strategy, innovation and consumer demand: A market process approach. Managerial and Decision Economics, 22(4-5), 183-199. https://doi.org/10.1002/mde.1016

Rohimah, A. (2019). Era Digitalisasi Media Pemasaran Online dalam Gugurnya Pasar Ritel Konvensional. KANAL: Jurnal Ilmu Komunikasi, 6(2), 91-100. https://doi.org/10.21070/kanal.v6i2.1931

Rojas-Méndez, J. I., Parasuraman, A., \& Papadopoulos, N. (2017). Demographics, attitudes, and technology readiness. Marketing Intelligence $\mathcal{E}$ Planning, 35(1), 1839. https://doi.org/10.1108/mip-08-2015-0163

Sani, A., Subiyakto, A., \& Rahman, T.K.A. (2018). Integration of the Technology Readiness and Adoption Models for Assessing IT Use among SMEs in Indonesia. International Conference On Recent Innovations. 3107-3113. https://doi.org/10.5220/0009948131073113

Sari, S. P. (2020). Strategi Meningkatkan Penjualan Di Era Digital. Scientific Journal Of Reflection: Economic, Accounting, Management and Business, 3(3), 291-300. https://doi.org/10.37481/sjr.v3i3.224

Saura, J. R. (2020). Using Data Sciences in Digital Marketing: Framework, methods, and performance metrics. Journal of Innovation and Knowledge, 6(2), 92-102. https://doi.org/10.1016/j.jik.2020.08.001

Schwab K., \& Porter, M. E., (2009). The Global Competitiveness Report 2008 - 2009. In World Economic Forum. Available at: http://www3.weforum.org/docs/WEF_GlobalCompetitivenessReport_2008-09.pdf

Şoavă, G., Sitnikov, C., \& Dănciulescu, D. (2014). Optimizing Quality of a System Based on Intelligent Agents for E-learning. Procedia Economics and Finance, 16, 4755. https://doi.org/10.1016/s2212-5671(14)00773-4

Sok, P., O'Cass, A., \& Sok, K. M. (2013). Achieving superior SME performance: Overarching role of marketing, innovation, and learning capabilities. Australasian Marketing Journal (AMJ), 21(3), 161-167. https://doi.org/10.1016/j.ausmj.2013.04.001

Sugiyarti, G., Ferdinand, A. T., \& Nurchayati, T. (2018). Acculturative products uniqueness antecedence for successful marketing performance. DLSU Business $\mathcal{E}$ Economics Review, 28(1), 86-96.

Sun, J. (2016). Tool choice in innovation diffusion: A human activity readiness theory. Computers in Human Behavior, 59, 283-294.

https://doi.org/10.1016/j.chb.2016.02.014

Tabachnick, B. G., \& Fidell, L. S. (2012). Using multivariate statistics (6th ed.). Pearson. Teece, D. J. (2013). Dynamic Capabilities and Strategic Management. Oxford University 
Press, Oxford.

Walker, J. H., Saffu, K., \& Mazurek, M. (2016). An Empirical Study of Factors Influencing E-Commerce Adoption/Non-Adoption in Slovakian SMEs. Journal of Internet Commerce, 15(3), 189-213. https://doi.org/10.1080/15332861.2016.1191049

Weber, W., \& Polo, E. F. (2010). Evolution of Generic Competitive Strategies and the Importance of Michael E. Porter. Revista de Gestão USP, 17(1), 99-117.

Westjohn, S. A., Arnold, M. J., Magnusson, P., Zdravkovic, S., \& Zhou, J. X. (2009). Technology readiness and usage: a global-identity perspective. Journal of the Academy of Marketing Science, 37(3), 250-265.

Wind, J., \& Mahajan, V. (1997). Issues and opportunities in new product development: An introduction to the special issue. SAGE Publications Sage CA: Los Angeles, CA.

Yang, Y., Wang, Q., Zhu, H., \& Wu, G. (2012). What are the effective strategic orientations for new product success under different environments? An empirical study of Chinese businesses. Journal of Product Innovation Management, 29(2), 166-179.

Yeh, C. H., Lee, G. G., \& Pai, J. C. (2015). Using a technology-organizationenvironment framework to investigate the factors influencing e-business information technology capabilities. Information Development, 31(5), 435-450.

Zhang, X., \& Qu, M. (2020). Impact of environmental regulation on scientific and technological competitiveness of resource-based cities in china-based on panel data of 33 resource-based cities. International Journal of Environmental Research and Public Health, 17(24), 1-16. https://doi.org/10.3390/ijerph17249187

Zhou, K. Z., \& Li, C. B. (2010). How strategic orientations influence the building of dynamic capability in emerging economies. Journal of Business Research, 63(3), 224-231. https://doi.org/10.1016/j.jbusres.2009.03.003

Zhou, K. Z., Yim, C. K., \& Tse, D. K. (2005). The effects of strategic orientations on technology-and market-based breakthrough innovations. Journal of Marketing, 69(2), 42-60. https://doi.org/10.1509\%2Fjmkg.69.2.42.60756 